\title{
The Significance of Flavonoids in the Process of Biological Nitrogen Fixation
}

\author{
Wei Dong and Yuguang Song * \\ School of Life Science, Qufu Normal University, Qufu 273165, China; dwei@qfnu.edu.cn \\ * Correspondence: syuguang@qfnu.edu.cn
}

Received: 9 July 2020; Accepted: 14 August 2020; Published: 18 August 2020

check for updates

\begin{abstract}
Nitrogen is essential for the growth of plants. The ability of some plant species to obtain all or part of their requirement for nitrogen by interacting with microbial symbionts has conferred a major competitive advantage over those plants unable to do so. The function of certain flavonoids (a group of secondary metabolites produced by the plant phenylpropanoid pathway) within the process of biological nitrogen fixation carried out by Rhizobium spp. has been thoroughly researched. However, their significance to biological nitrogen fixation carried out during the actinorhizal and arbuscular mycorrhiza-Rhizobium-legume interaction remains unclear. This review catalogs and contextualizes the role of flavonoids in the three major types of root endosymbiosis responsible for biological nitrogen fixation. The importance of gaining an understanding of the molecular basis of endosymbiosis signaling, as well as the potential of and challenges facing modifying flavonoids either quantitatively and/or qualitatively are discussed, along with proposed strategies for both optimizing the process of nodulation and widening the plant species base, which can support nodulation.
\end{abstract}

Keywords: flavonoids; biological nitrogen fixation; endosymbiosis; nodulation; actinorhiza; arbuscular mycorrhiza

\section{Introduction}

The flavonoids form a large group of plant secondary metabolites synthesized by the phenylpropanoid pathway: over 9000 distinct compounds have been characterized to date [1]. The major recognized subgroups are the chalcones, flavones, flavonols, anthocyanins, proanthocyanidins and aurones [2] (Figure 1). A wide range of plant processes makes use of flavonoids, and these include protection from harmful radiation, sexual reproduction, defense against pests and pathogens and tissue pigmentation. Their synthesis involves a number of discrete enzymatic steps [3]. In the model angiosperm Arabidopsis thaliana, most of the relevant enzymes are encoded by a single-copy gene [4]. Flavonoids are synthesized in the cytosol [5] and are typically stored in the vacuole [6], but some are exuded into the rhizosphere [7]. The synthesis of a given flavonoid can be either organ- and/or tissue-dependent, and can be affected by the plant's external environment, in particular by light intensity, ambient temperature and the availability of nitrogen [8,9]. The lateral root and nodule primordia of the legume subterranean clover (Trifolium subterraneum) is particularly rich in flavonoids [10], as is the root tip and lateral root primordia of $A$. thaliana [11].

The process of biological nitrogen fixation converts atmospheric nitrogen into ammonium, a form that is readily utilized by plants. The ability of some plant species to supply some, if not all of their requirement for nitrogen in this way gives them a substantial competitive advantage over those that lack this ability. According to some estimates, biological nitrogen fixation is responsible for the fixation in the agricultural system of up to 200 MT of nitrogen annually, representing a major saving in the cost (both financial and environmental) of crop production. The only micro-organisms able to carry out biological nitrogen fixation are those that produce nitrogenase, an enzyme that is required to catalyze 
the conversion of atmospheric nitrogen to ammonium. In a highly restricted group of plant species, the association between the host plant and the bacterial symbiont is a highly intimate one: the bacteria are housed within nodules, a specialized organ that forms in the root. Several nitrogen-fixing bacterial species are known to associate with non-nodulating plants; while these bacteria are generally free-living in the rhizosphere, in some cases they are able to colonize non-specialized intercellular spaces within the plant root [12]. The efficiency with which nitrogen is transferred to the plant by such bacteria is, however, relatively low, and the relationship between the two organisms is regarded as opportunistic rather than mutualistic. In genuine mutualistic symbioses, the host and symbiont appear to function essentially as a single organism [13].

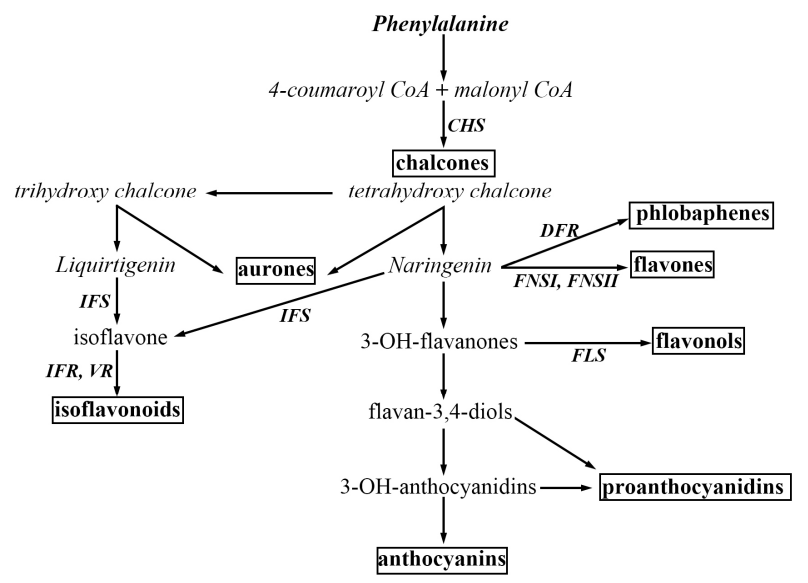

Figure 1. Major branches of the flavonoid biosynthesis pathway. Some of the critical enzymes are abbreviate as follows: CHS, chalcone synthase; DFR, dihydroflavonol 4-reductase; FSI/II, flavone synthase I/II; FLS, flavonol synthase; IFS, isoflavone synthase; IFR, isoflavone reductase; LCR, leucoanthocyanidin reductase; VR, vestitone reductase. Major classes of end-products are emphasized in boxes.

Two types of intracellular endosymbiosis have been recognized, namely one which requires the formation of a root nodule, and one that relies on arbuscular mycorrhizae (AM) [14] (Figure 2A). The root nodule has evolved to facilitate both nitrogen fixation by the symbiont and the assimilation of ammonium by the host plant. Within the nodule, the symbiont receives its carbon and energy from the host and in return converts atmospheric nitrogen to ammonium, a process that requires an anaerobic environment. The bacteria capable of establishing this form of symbiosis belong to two distantly related clades, namely the proteobacterial Rhizobium spp. and the actinobacterial Frankia spp. Meanwhile the host species all belong to the so-called "nitrogen-fixing clade" [15], which consists of species within either the order Fabales (nodulated by the Rhizobium spp.) or the three orders Cucurbitales, Fagales and Rosales (nodulated by the Frankia spp.) [16]. Phylogenetic analyses suggest that all nodulating plant species belong to the Fabid (Eurosid 1) clade [15]. AM-based symbioses are, in contrast, very widespread in the plant kingdom, involving at least $80 \%$ of all angiosperm species; the microbial partners are not bacteria, but rather are fungi belonging to the phylum Glomeromycota [3]. They themselves do not fix nitrogen, but many studies have demonstrated that the presence of AM in the rhizosphere enhances the colonization of legume host roots with Rhizobium spp. Some features of root nodule endosymbiosis may have been recruited from the more ancient AM symbiosis [17] (Figure 2b), which has prompted the hypothesis that the two processes share aspects of the early signaling events [18]. Flavonoids are known to be required for the establishment of nodules in legumes, and are thus likely also to be important in both actinorhizal and AM symbioses [10]. This review aims to summarize our current understanding of the signaling and control of flavonoids in the biological nitrogen fixation process. 


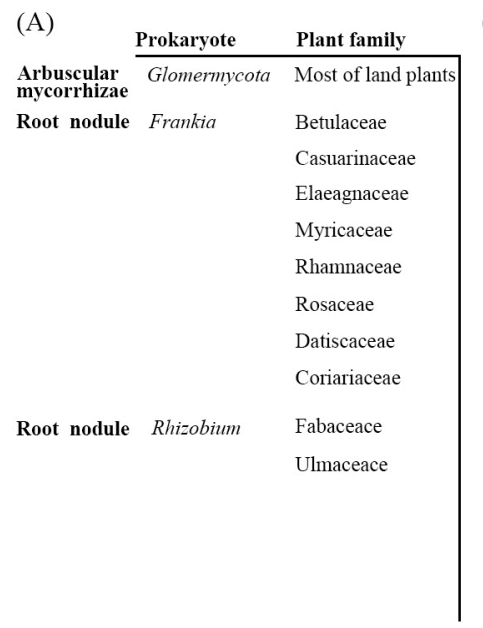

(B)

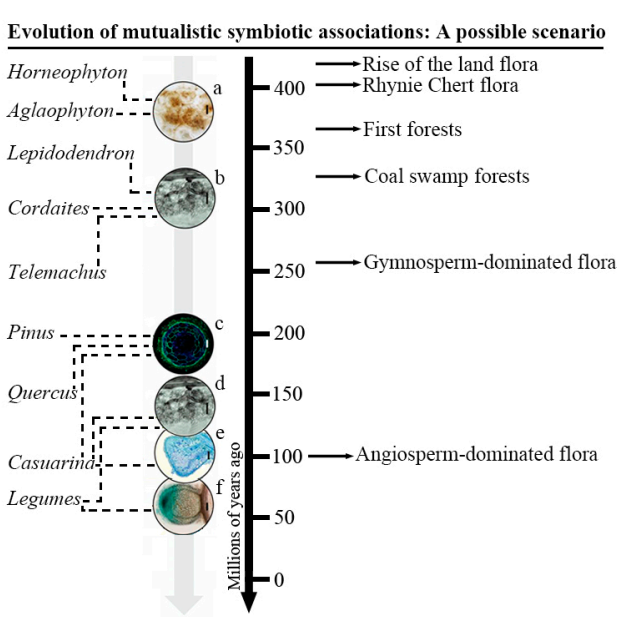

Figure 2. Plant families that participate in intracellular endosymbiosis (A) and the evolution of mutualistic symbiotic associations: a possible scenario (B) (modified from Martin et al., 2017 [19]); a, arbuscular mycorrhiza-like and/or mucoromycotina associations; b, arbuscular mycorrhiza; c, ectomycorrhiza; d, arbuscular mycorrhiza; e, Frankia N-fixing; f, Rhizobial N-fixing.

\section{Flavonoids and Legume Symbiotic Nitrogen Fixation}

The legume family (Fabaceae) is the third largest family of flowering plants, with members of more than 650 genera, 18,000 species spread around the globe [20]. Part of their evolutionary success is due to their symbiosis with the Rhizobium spp., which enables the plants to tolerate soils thatare deficient in nitrogen. In natural ecosystems, the quantity of nitrogen fixed by legumes is estimated to be $28-84 \mathrm{~kg}$ per hectare per year, while in a cropping environment, this can rise to several hundred kilograms per hectare [21,22]. Legume symbionts adopt one of three strategies to achieve biological nitrogen fixation, namely the Nod strategy, the T3SS (type III secretion system) strategy and the non-Nod/non-T3SS strategy (Figure 3). It was well verified that flavonoids released by the roots of legume species regulate the Nod strategy [10]. Besides that, flavonoids participate in several other different stages of the nodulation process, such as the chemoattraction of Rhizobium, the T3SS strategy, the development of nodule, the symbiont selection and so on.

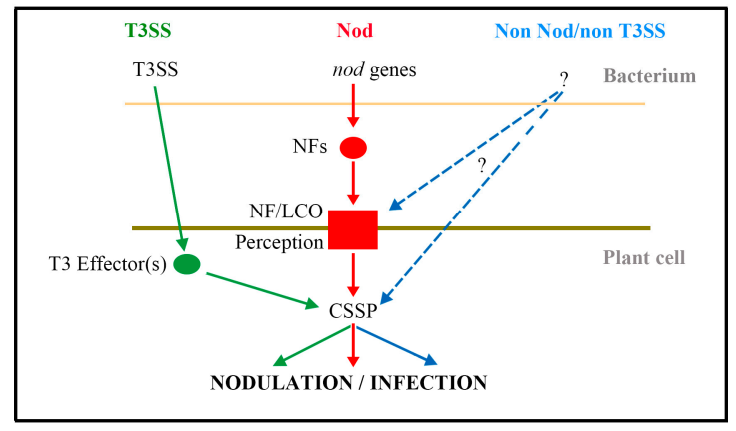

Figure 3. Nodulation strategies in legume symbionts (modified from Catherine and Joel, 2018 [22]). In the Nod strategy, strain-specific lipochitin oligosaccharides (LCO) called Nod factors (NFs) are produced under the control of nod genes. NFs are perceived by plant NF receptors that activate the common symbiotic signaling pathway (CSSP). In the T3SS strategy, T3SS effectors activate CSSP components by bypassing NF recognition. The mechanism of the third nodulation strategy is still unknown, but it involves neither nod nor T3SS functions and occurs via CSSP activation.

\subsection{Flavonoids Regulate the Expression of Nod Genes}

A well-studied effect of root-exuded flavonoids is their regulation of Rhizobium spp. nod genes [23]. This function of flavonoids was discovered, dating back to 1986 when luteolin in Medicago sativa [24] 
and 7,4' dihydroxyflavone in T. repens [25] were found to act as nod genes inducers. The concentration of flavonoid required for this induction is typically in the nanomolar to low micromolar range, and mixtures of different flavonoids can be more effective than a single compound [26]. In most $\alpha$ - and $\beta$ proteobacteria rhizobial species, as has been reviewed elsewhere $[27,28]$ (Figure 4), a number of nod gene products co-operate to synthesize the Nod factors required for nodule formation. These nod genes are regulated by NodD, a LysR family transcription factor. The binding of an appropriate flavonoid to NodD is thought to facilitate the access of RNA polymerase and thereby to enhance the transcription of the nod genes. The NodD-flavonoid complex binds to its target DNA sequences, known as a nod box. The perception of flavonoids by Rhizobium spp. is associated with a rise in the concentration of cellular calcium, which acts to induce the expression of NodD [29]. Secreted nod factors are recognized by plant LysM receptor-like kinases, triggering the characteristic curling of the root hair tip back on itself, thereby trapping the symbiont cells within a pocket, from which they are taken up into the root proper via an infection thread [30]. Once they reach the inner root, they are endocytosed into nodule cells and begin to fix nitrogen. Nod factors also induce cell division, as well as gene expression in the root cortex and pericycle, which initiates the development of the nodule [31,32].

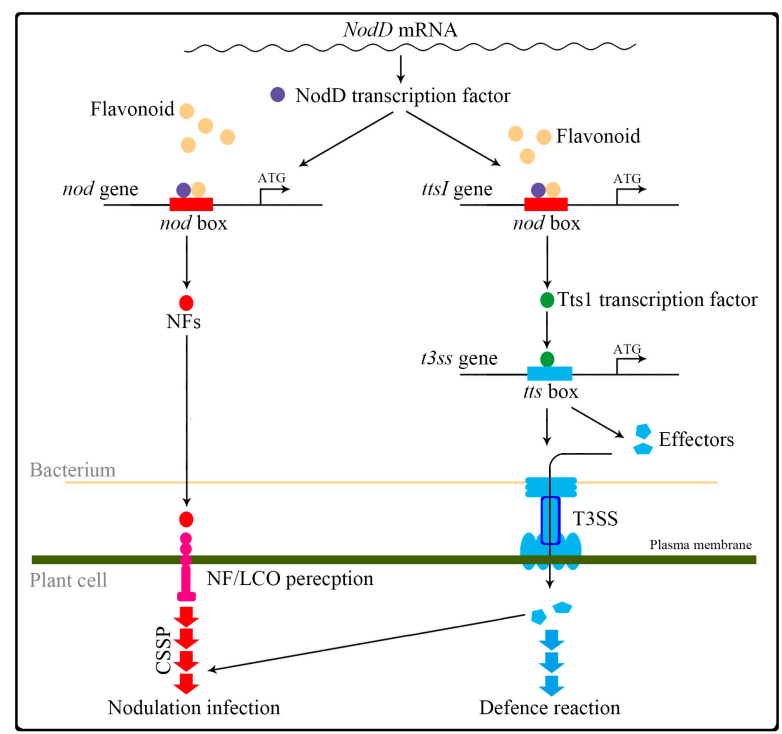

Figure 4. Contrasting cascades for the Nod and T3SS mechanisms.

\subsection{Flavonoids Regulate the Expression of Genes Acting in the T3SS Strategy}

Flavonoids also induce a number of genes responsible for the T3SS process (Figure 4) in some rhizobial species, such as B. elkanii USDA61 [22,33]. Most of these genes include a tts box cis element in their promoter region and their expression frequently depends on the presence of the TtsI transcription factor, which binds to the $t$ ts box. Expression of $t t s I$ (as determined by promoter-lacZ reporter gene fusion constructs) is strongly induced by flavonoids in a NodD-dependent manner, because the promoter of ttsI, like that of the nod gene, contains the nod box [34]. The secretion of some Rhizobium spp. T3SS proteins-in particular certain Nops (nodulation outer proteins; also called T3 effectors)—is induced by flavonoids produced by the host $[35,36]$. These proteins act to suppress the host's pathogen defense response and to promote several processes required to establish a symbiosis. Some Nops are thought to promote symbiosis more directly by interfering with the host's nodulation signaling machinery [34]. Nops are passed from the Rhizobium spp. cells' cytoplasm through the lumen of needle-like structures, which appear in electron micrographs as appendages referred to as T3 pili [37]. The capacity to form a viable symbiosis is compromised in mutant Rhizobium spp. strains deficient with respect to the synthesis of or secretion ability of T3 pili [38-40]. The expression of Nops genes, like that of most of the genes involved in T3SS, relies on the presence of NodD and particular host-derived 
flavonoids. For example, only when Rhizobium cultures are provided with flavonoids is it possible to immunologically detect the presence of both NopX and NolT [41] and for long T3 pili to form [42].

\subsection{Flavonoids Act as Chemoattractants and Growth Stimulants for Rhizobium spp.}

That flavonoids can act as a chemoattractant of Rhizobium spp. has been inferred from the observation that their abundance is high in the vicinity of the root tip $[43,44]$ and particularly so near emerging root hairs, at which, Rhizobium spp. infection is initiated [45]. Sinorhizobium meliloti cells use flavonoids to promote their movement toward its host's roots [46] and the concentration of flavonoid involved varies from $1 \mu \mathrm{M}$ to as little as $0.1 \mathrm{nM}$, a much lower level than is required to induce nod genes. Flavonoids can also regulate the growth of Rhizobium spp. For example, the growth of both Bradyrhizobium japonicum and S. meliloti cells was enhanced by the provision of daidzein, luteolin-7xO-glucoside or quercetin-3-O-galactoside produced by alfalfa $[47,48]$. The inclusion of either host plant exudate or the flavonoids naringenin and apigenin in the medium used to grow Bradyrhizobium sp. in vitro significantly enhances cell multiplication [7]. A similar effect is exerted by a number of simple phenolic acids (p-coumaric, caffeic, protocatechuic, p-hydroxybenzoic and phenyllactic acids) present in the rhizosphere as flavonoid breakdown products [49].

\subsection{The Influence of Flavonoids over Nodule Development and Number}

Auxin is synthesized locally in the shoot apex, the leaf primordia and the developing seed, and is subsequently transported away from the site of its synthesis by polar auxin transport [10]. Treating some legume species with a synthetic auxin transport inhibitor has long been known to induce the formation of pseudo-nodules; these structures contain a peripheral vasculature, which does not extend into its distal region, a central zone and a diffuse meristem [50]. Flavonoids regulate both the transport and breakdown of auxin during nodule development (Figure 5). Thus, flavonoids can potentially act within the root to control nodule development and differentiation [51]. It has been suggested that Nod factor perception induces certain flavonoids that inhibit auxin transport, thereby promoting the localized accumulation of auxin at the nodule initiation site, leading to the initiation of nodule primordia [52]. This notion has been experimentally validated by silencing the gene encoding chalcone synthase in the Medicago truncatula root [53]. Silencing various branches of the flavonoid pathway in M. truncatula shows kaempferol to be the flavonoid most likely able to inhibit auxin transport during nodulation [54]. Whether auxin transport is regulated by the nodulation process, leading to the determination of nodules in, for example, soybean, remains unclear, but it is likely that other flavonoids (possibly isoflavonoids) are also involved [55]. Silencing of the isoflavonoid synthesis pathway in soybean altered auxin-inducible gene expression and auxin transport in the roots, but this effect can be overcome either by inoculation with a genistein-hypersensitive B. japonicum strain or by providing purified B. japonicum Nod signals [55]. The nature of how flavonoids affect auxin transport is not known, but the evidence from experiments using $A$. thaliana suggests that flavonoids affect the vesicular cycling of PIN family auxin transporters, possibly through interactions with other regulatory proteins such as phosphatases and kinases [56,57]. Abolishing the activity of isoflavone reductase in the common bean reduces the number of nodules formed, while simultaneously down regulating the gene GH3 [58]. In M. truncatula abolishing the activity of chalcone synthase however, has no effect on lateral root development [59]. Auxin accumulation can also be influenced by the rate of its peroxidase-induced breakdown, a process that can be modulated by flavonoids. The isoflavonoid formononetin, which accumulates in the nodule primordia of white clover, accelerates auxin breakdown, while 7,4'-dihydroxyflavone (and its glycosides), which accumulate in the vacuoles of the cortical cells that later form the nodule primordia, inhibit its breakdown [60]. The differential ability of flavonoids and the availability of a large range of such metabolites give plants a means to regulate nodule development. 


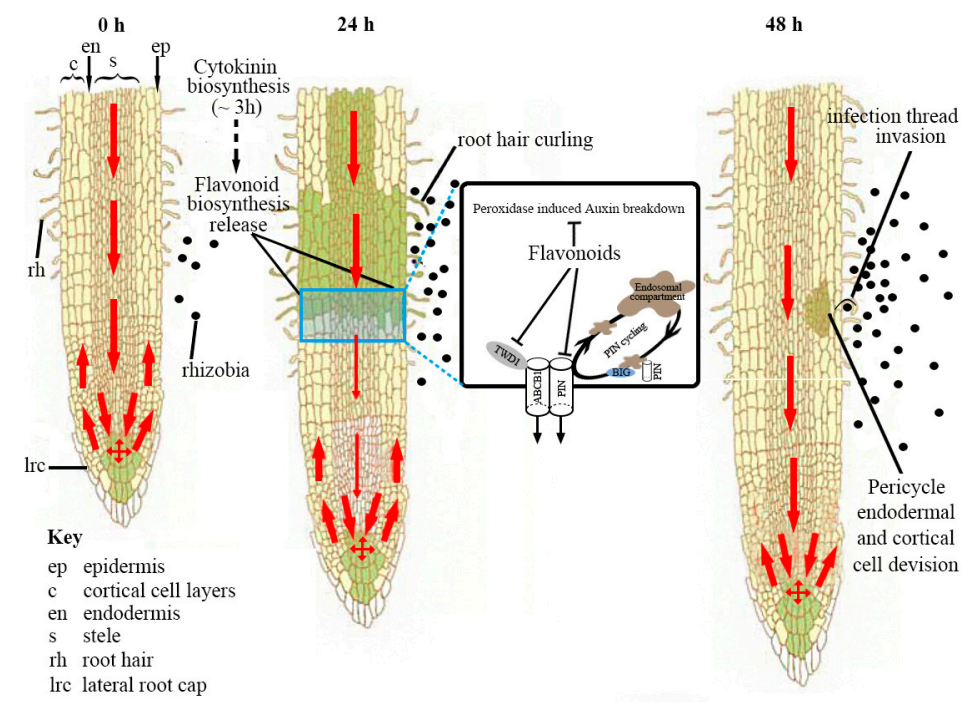

Figure 5. Schematic model of the regulation of auxin transport during nodulation in Medicago truncatula. Before rhizobia infection, auxin is transported in the acropetal direction towards the root tip. Auxin is also transported in the basipetal direction (from root tip to elongation zone) in the outer layer(s). Within $3 \mathrm{~h}$ after symbiosis induction (lipochitooligosaccharide treatment), cytokinin biosynthesis is upregulated in M. truncatula roots [61]. Cytokinin perception at the inner cortex induces/releases certain flavonoids, which act as inhibitors of acropetal auxin transport at the inner cortical, endodermal and/or pericycle directly underlying the rhizobia infection site [62]. Flavonoids are auxin transport inhibitors thought to disrupt the complex between ABCB1 (ATP-Binding Cassette Subfamily B 1) and TWD1 (TWISTED DWARF1) [63,64], affecting transport, and by binding BIG, a protein required for PIN cycling [65]. The reduction of acropetal auxin transport increases auxin concentration at the rhizobia infection site, the location of a future nodule primordium. An increase in basipetal auxin transport could also contribute to the increased auxin pool at the nodulation site [62]. Pericycle, endodermal and cortical cell divisions are activated within $48 \mathrm{~h}$. The red arrow shows the polar auxin transport and the arrow thickness proportional to auxin transport capacity. The green color shows the auxin gradient and the darker color denotes higher auxin content.

Flavonoids may also participate in the systemic regulation of the nodule number. Split root experiments have demonstrated that the content of isoflavonoid formononetin (and its glycoside ononin) is reduced in both Rhizobium spp.-induced and AM-induced symbioses in a systemic manner, suggesting that a related autoregulation signal affects their synthesis [66]. The exogenous supply of ononin is able to only partially restore nodulation and mycorrhization, which was taken to imply that flavonoids actively control symbiosis [66]. Similarly, a comparison of grafts involving a supernodulating soybean shoot or a wild type soybean shoot with a wild type common bean root has shown that the accumulation of isoflavonoids in the root is higher in the former case [67]. The exogenous supply of either daidzein or coumestrol increases the nodule number and enhances bacterial growth in vitro [67]. It is possible that systemically accumulated flavonoids control auxin transport in autoregulated roots, since in M. truncatula, auxin transport has been shown to be modulated during autoregulation [68].

\subsection{The Contribution of Flavonoids to Symbiont Selection}

The Rhizobium spp. legume symbiosis is highly host-specific: that is, a given Rhizobium spp. strain is only able to form a successful symbiotic relationship with a limited set of host plant species and vice versa [69]. The combination of host flavonoids appears to be a major determinant as to which Rhizobium spp. are able to successfully establish a symbiotic relationship. The affinity between NodD and flavonoids in part determines the host range: it has been shown that the NodD protein produced by a broad host range Rhizobium spp. strain interacts with a greater number of flavonoids than does NodD produced by a narrow host range strain [70]. For a given flavonoid to make a significant 
contribution to determining whether or not the host and the symbiont will be compatible, it has to be a strong inducer of nod genes, be represented in the host root exudate and be required for Rhizobium spp. infection and its synthesis should respond positively to the presence of the symbiont's Nod protein [71]. In the soybean/Bradyrhizobium spp. symbiosis, genistein has been shown to be a strong and selective nod gene-inducer, activating NodD from B. japonicum but not B. elkanii [72].

The combination of flavonoids present in the root exudate of legume species acts as a selective agent for compatible symbiotic organisms. For example, medicarpin, a flavonoid produced by both Trifolium and Medicago species, exerts an inhibitory effect on incompatible bacterial strains [73]. Methoxychalcone is the strongest nod gene inducer identified in the Medicago root exudate. All four $M$. truncatula genes encoding chalcone-O-methyltransferase, the key enzyme required to synthesize methoxychalcone, are induced in the root hairs of plants inoculated with a compatible Rhizobium spp. strain [74]. However, in soybean, none of the six genes encoding chalcone-O-methyltransferase are induced in the root hairs of plants being colonized by Bradyrhizobium sp. [75]. The implication is that the synthesis of methoxychalcone is not a general response to Rhizobium spp. infection.

A further determinant of the host range of a Rhizobium spp. strain is associated with its surface polysaccharides and secreted proteins/T3SS [23]. Surface exopolysaccharides required for establishing a successful symbiosis can be modified by flavonoids either during or after the synthesis of exopolysaccharides [76]. Exposure of $R$. fredii cells to $1 \mu \mathrm{M}$ genistein alters their exopolysaccharides, both quantitatively and qualitatively [77]. Flavonoids also regulate most of the genes utilized in the T3SS process. Low concentrations of certain isoflavonoids can induce resistance in compatible symbiotic bacteria to the potentially bactericidal phytoalexins present in some root exudates [26].

\subsection{Flavonoids Act during Nodulation as Phytoalexins}

Phytoalexins are low molecular weight antimicrobial compounds that are produced by plants as a response to biotic and abiotic stresses. Flavonoids can act as suppressors of rhizosphere micro-organisms competing with Rhizobium spp. for colonization. Some key flavonoids have been identified in both soybean and M. truncatula as being required for the initiation and progression of infection, acting as phytoalexins to reinforce specificity [71]. Several studies have shown that during nodulation, not only is the abundance of nod gene-inducing flavonoids increased, but is that of flavonoids endowed with antibacterial and/or antifungal activity. While the production of phytoalexins during nodulation may at first seem to be counter-productive, it appears that these phytoalexins are not part of a generalized defense response, and many of them are not inducers of nod genes [75]. Indeed medicarpin, for example, even acts to repress nod gene transcription [75]. Methoxychalcone is a potent antagonist of Gram-positive bacteria [78], while genistein possesses both antifungal and antibacterial activity [34]. The flavonoid and NodD1dependent secretion of Nops is in a sense a double-edged sword: on the one hand promoting the establishment of symbiosis with one legume species and on the other impairing it with a different host species [79]. The direct or indirect recognition by the host of NopP in Sinorhizobium fredii HH103 [80] can activate a plant defense response inhibiting the infection by Rhizobium spp. and subsequent nodule formation. This sort of response is likely similar to the effector-triggered immunity documented in certain plant-pathogen interactions [81]. The apparently universal role of flavonoids as phytoalexinsin plants suggests that, along with their role in determining the Rhizobium spp. host range, their role in defense has likely been a key driver in the expansion and diversification of the legumes.

\subsection{Flavonoids in Symbiosis Quorum-Sensing}

Quorum sensing is a system of stimulus and response correlated to population density. Many species of bacteria use quorum sensing to coordinate gene expression according to the density of their local population. The processes of nodulation, symbiosome development, exopolysaccharide production and nitrogen fixation all depend on the ability of Rhizobium spp. cells to accumulate in and around a host plant's roots and nodules. The symbiont's global profile of gene expression, 
including that of genes encoding the key components of nitrogen fixation [82], is strongly dependent on quorum sensing. A number of higher plant species are able to synthesize mimics of bacterial quorum sensing compounds, the best characterized of which are the acyl homoserine lactones (AHLs). Some of these mimic compounds have proven to be flavonoids [83], of which the most prominent example is naringenin. This flavonoid acts not just as an inducer of nod gene expression, but also as a strong inhibitor of quorum sensing in Pseudomonas aeruginosa [84], as well as in both Escherichia coli and Vibrio fischeri [85]. Experiments conducted in M. truncatula have demonstrated that certain bacterial AHLs are able to stimulate the production of AHL mimics [86]. The implication is that there may well be a link between a plant's perception of AHL and the activation of its flavonoid pathway, while at the same time there may be a feedback mechanism in the bacterial species. Critical threshold concentrations in the rhizosphere of flavonoid mimics have yet to be defined. The boost in the synthesis of AHLs generated by exposure to nod gene-inducing flavonoids reported in three different Rhizobium spp. [26] suggests that a level of coordination exists between nod gene induction and quorum sensing. The formation of biofilms relies both on effective quorum sensing and on the presence of certain bacterial surface components [87]. In Sinorhizobium fredii, the presence of nod gene-inducing flavonoids and the NodD1 protein is required for the transition of a biofilm monolayer into a microcolony [88]. The possibility that flavonoids mimic quorum sensing compounds and, when present at a relevant concentration, can activate gene expression in rhizosphere bacteria suggests a means of manipulating the ability of bacteria to colonize their host plant.

\section{Flavonoids in Actinorhizal Plant Nitrogen Fixation}

Only a single family of host plants have succeeded in evolving a symbiotic relationship with Rhizobium spp., whereas the symbiosis between the actinobacterium Frankia spp. involves plants belonging to eight families: namely the Betulaceae, Myricaceae, Rosaceae, Datiscaceae, Elaeagnaceae, Coriariaceae, Casuarinaceae and Rhamnaceae [89]. Except for herbaceous species belonging to the genus Datisca, these so-called "actinorhizal" plants are all woody shrubs or trees, many of which are adapted to highly marginal environments [90], such as the sandy dunes in Africa where Casuarinaceae species, through their association with Frankia spp., have been recorded as able to fix an average of $15 \mathrm{~kg}$ nitrogen per ha per year. In some temperate environments, the capacity of actinorhizal plants to fix nitrogen can reach $300 \mathrm{~kg}$ nitrogen per ha per year [90]. Analysis of Frankia spp. genome sequences has failed to reveal any evidence for the presence of nod gene clusters [26], which implies that their mode of symbiosis differs markedly from that used by Rhizobium spp. On the other hand, it is becoming clear that flavonoids are central to the process of actinorhizal nitrogen fixation.

\subsection{Flavonoids May Act as Signals for Establishing Actinorhizal Symbioses}

While the molecular basis of the involvement of flavonoids in actinorhizal symbiosis remains poorly understood, the general assumption is that a compatible interaction between Frankia spp. and an actinorhizal plant relies on an exchange of signals between the two partners, with some indication that flavonoids participate in signaling, at least during the initial stage of the interaction [26]. Flavonoids accumulate inside the actinorhizal nodule. Nodule formation by Frankia on the roots of red alder (Alnus rubra) is promoted by irrigation with flavonoid-containing seed washes prepared from the host species [91], and these results were reinforced by treatment with the quercetin and kaempferol contained in black alder (Al. glutinosa) root exudates [92]. The curling of root hairs, a key early event in the establishment of a symbiosis, can be promoted by exposing Frankia spp. cells to a filtrate prepared from the roots of Al. glutinosa [93]. Direct evidence for the participation of flavonoids during the early stages of actinorhizal nodulation has been provided by showing that abolishing the activity of chalcone synthase (the first enzyme of the flavonoid pathway) in Casuarina glauca significantly compromises nodulation [14]. Exudate from the fruit of Myrica gale influences the transcription of 22 Frankia spp. genes, while inoculation of $M$. gale with Frankia spp. alters the level of transcription of several genes acting in the flavonoid synthesis pathway [94]. An analysis of a C. glauca root and nodule expressed 
sequence tag (EST) database has revealed the identity of eight genes encoding enzymes involved in the flavonoid synthesis [95].

\subsection{Flavonoids May Contribute to the Determination of Host Specificity}

Flavonoids extracted from fruit of $M$. gale enhance both the growth and the efficiency of nitrogen fixation achieved by a compatible Frankia sp. strain, but has a negative effect on an incompatible strain [94], which implicates flavonoids in the process of the host's selection of a symbiont. Flavonoid-containing extracts of the root of $C$. cunninghamiana have been found to alter certain surface components of a compatible Frankia sp. strain in relation to infectivity [96], and some experimental evidence supports the notion that flavonoids are involved in both the chemoattraction and proliferation of Frankia spp. cells in the rhizosphere [97].

\subsection{Flavonoids May Be Involved in Nodule Development and Function}

In the C. glauca/Frankia spp. symbiosis, flavan class flavonoids are accumulated specifically in the nodule lobes [98]. Although the same compounds can be found in both nodules and non-infected roots, the amount of each flavan is much higher in the former. The application of in situ hybridization technology has established that transcripts of the gene encoding chalcone synthase accumulate in flavan-containing cells present at the apex of the nodule lobe. The significance of this compartmentation is not understood, but its development clearly requires the exchange of signals between the host and the symbiont. Similarly, in Elaeagnus umbellata, the abundance of transcript generated from the gene encoding chalcone isomerase is particularly high in nodules, increasing during nodule development [99].

The observations that the C. glauca auxin influx carrier gene $A u x 1$ is upregulated during actinorhizal nodule formation [100] and that auxin is produced by Frankia spp. [101] suggest that auxin influences the actinorhizal infection process. The accumulation of auxin within the C. glauca actinorhizal nodule is the result of both the localized expression of auxin transporter-encoding genes and the synthesis of auxin in planta by the Frankia spp. symbiont [102]. Metabolomic and transcriptomic analyses of Datisca glomerata have demonstrated an abundance of flavonols, which are particularly powerful inhibitors of auxin transport [16]. Analysis of nascent nodules formed during the C. glauca/Frankia spp. interaction has revealed that genes encoding isoflavonoids are prominently transcribed, suggesting that these compounds too are important for the nodulation process [103] and isoflavonoids also have the capability to control auxin transport. The possibility is therefore, that as in the legumes, flavonoids also act as auxin transport inhibitors during actinorhizal symbiosis, thereby promoting the localized auxin accumulation required for nodule development.

\section{The Participation of Flavonoids in the Tripartite (Legume/AM/Rhizobium spp.) Symbiosis}

Once the hyphae of AM penetrate a host plant root, they form ecto- or endomycorrhizal invasion structures [104]. The host root exudate, which is able to stimulate the germination of the AM's spores, the branching of its mycelium and its colonization of the host, contains a number of flavonoids $[105,106]$, at concentrations varying in the range $0.5-20 \mu \mathrm{M}$. The isoflavonoid coumestrol has been identified as a particularly active stimulator of hyphal growth [28], while a M. truncatula mutant that hyperaccumulates coumestrol is particularly strongly colonized by its AM symbiont [107]. In most herbaceous legume species, a tripartite symbiosis can form between the plant, Rhizobium spp. and AM [108] The effectiveness of this symbiosis in terms of nitrogen fixation is higher than that of the bipartite legume/Rhizobium spp. interaction $[109,110]$. According to FAO estimate, it has been estimated that $175 \mathrm{Mt}$ nitrogen is fixed annually worldwide in this way, contributing materially to a reduction in dependence on synthetic fertilizers and to the sustainability of agriculture and agroforestry. Metabolite profiling of the roots of $M$. truncatula colonized by AM has revealed that flavonoids accumulate at various stages of the colonization process [111]. Similarly, an elevated abundance of transcript generated from genes encoding phenylalanine ammonia lyase and chalcone synthase can be detected in 
the roots of M. trunculata colonized by the AM species Glomus versiforme [112]. In T. repens, the flavonoid composition of extracts of the shoot and root of plants grown in the presence of AM differs markedly from that of plants grown in its absence [113]. It is possible that the tripartite symbiosis is effective in promoting nodulation because flavonoids induced by the AM partner stimulate the synthesis of Nod factors. Soybean plants respond to the presence of AM by boosting their production of daidzein [114], a compound that acts as a nod gene inducer [115]. The flavonoids genistein and coumestrol along with daidzein have been identified as potential signaling compounds regulating the establishment of the soybean/AM/Bradyrhizobium sp. tripartite symbiosis [116]. The synthesis of coumestrol (a nod gene inhibitor in S. meliloti) by M. truncatula is induced by the presence of AM symbionts [112]. However, evidence showed that although the profile of flavonoids produced by soybean plants supported by both Rhizobium spp. and AM responds to both symbionts: the accumulation of flavonoids (including those which induce nod genes and hyphal branching) is inhibited by the symbionts, even though co-inoculated plants enjoy a higher degree of nodulation than those inoculated with Rhizobium spp. [117]. The enhanced degree of symbiosis exhibited by tripartite interactions may, therefore, be more the result of their superior ability to take up nutrients than to any stimulatory effect of flavonoids.

In summary, it seems likely that changes in the flavonoid profile are responsible for the regulation of the initial phase of an AM association, and that a tripartite association can enhance the efficacy of the nitrogen fixation process carried out by legumes. The recent recognition that strigolactones, which are present in root exudates, can act as host-recognition signals for AM [118] casts some doubt over the assumption that flavonoids act as signaling molecules [119]. In addition, the colonization of mutualistic fungus Phomopsis liquidambari increases auxin signaling in Arachis hypogaea as well as nodulation and nitrogen fixation of the host. It may also be of value to examine the possibility that flavone compounds act as inhibitors of auxin transport.

\section{The Potential of Manipulating Flavonoids to Improve Biological Nitrogen Fixation}

Supplementation of inoculants with flavonoids is already in commercial use as a means of promoting legume-Rhizobium symbiosis [120]. For example, the product SoyaSignal ${ }^{\mathrm{TM}}$ includes added genistein and daidzein, which induce the expression of B. japonicum nod genes. The possibility of manipulating the root-rhizosphere interaction (and in particular biological nitrogen fixation) by modifying the plant's flavonoids composition and/or content has been suggested as a fruitful line of research. For the moment though, the relevant technology has yet to be developed, awaiting a better definition of the nature of the interactions involved between the host plants, the various flavonoids and the relevant soil micro-organisms. Due to the biological complexity of the rhizosphere, it is possible that altering the content of a particular flavonoid will influence the performance of symbiotic and/or pathogenic soil micro-organisms, and even that of non-target plants; such unforeseen effects will need to be borne in mind and explored. While certain flavonoids may indeed enhance nodulation and/or mycorrhization, they may also have an effect on bacterial quorum sensing, plant-plant interactions and soil biochemistry. Catechin, as an example, has been suggested to negatively impact the quorum sensing of desirable micro-organisms, to the extent that it could represent a potent allelopathic signaling compound, acting to suppress plant growth $[85,121]$. Similarly, naringenin, a compound recognized as an inducer of nod gene expression in several Rhizobium spp., may affect the regulation of quorum sensing of non-target bacteria [122,123]. The isoflavonoids present in soybean root exudate attract not only the symbiont B. japonicum but also the highly damaging pathogen Phytophthora sojae [124]. Furthermore, the presence in the rhizosphere of flavonoid metabolic breakdown products has the potential to affect the activity and availability of the flavonoid itself and even to have a harmful effect on beneficial micro-organisms [125]. Given that flavonoids can modify the structure of the rhizosphere microbial community, an important direction of future research will be to apply DNA-based approaches, such as the high throughput sequencing of 16s rRNA, to track changes in species representation in the rhizosphere in response to the manipulation of flavonoids. At the same time these data could 
improve the level of understanding of the functional role of the various flavonoids in the activity of both symbiotic and non-symbiotic rhizosphere species.

The restricted host range characteristic of the legume-Rhizobium symbiosis has given rise to a great diversity of flavonoids and Nod factors, only few of which have been studied in any detail. Given that the legumes represent the third largest family in the plant kingdom, the potential number of distinct Nod factor/flavonoid combinations will likely be very large; thus the benefits to be gained from rhizosphere engineering could well be substantial. The realization of this potential will, however, require a step increase in research efforts directed at the identification of host determinant factors and a detailed characterization of the infection process. In contrast to the legume-Rhizobium interaction, the symbiosis between actinorhizals and Frankia spp. remains rather poorly characterized. Nevertheless, the overall similarity between these two processes implies that gaining a more profound understanding of the significance of flavonoids in the process of nitrogen fixation in the legumes will also likely shed light on the mechanisms underlying actinorhizal nitrogen fixation.

\section{Conclusions}

From the results above described, it is evident that even if the role of flavonoids have been well characterized in legumes nodulation with Rhizobium, several question marks still remain for their role in the legume/Rhizobium/AM tripartite symbiosis and actinorhizal symbioses (Figure 6). The discovery that actinorhizal species and legumes share a common symbiotic signaling pathway [126] suggests that a major research challenge will be to identify which flavonoids are in common to both the Rhizobium spp. and the AM symbiosis, and which are unique [26]. Gaining this understanding could guide strategies based on manipulating the flavonoid pathway, aiming to either improve the efficacy of the natural symbiotic systems or even to transfer the ability to fix biologically nitrogen from legumes into cereals [127].

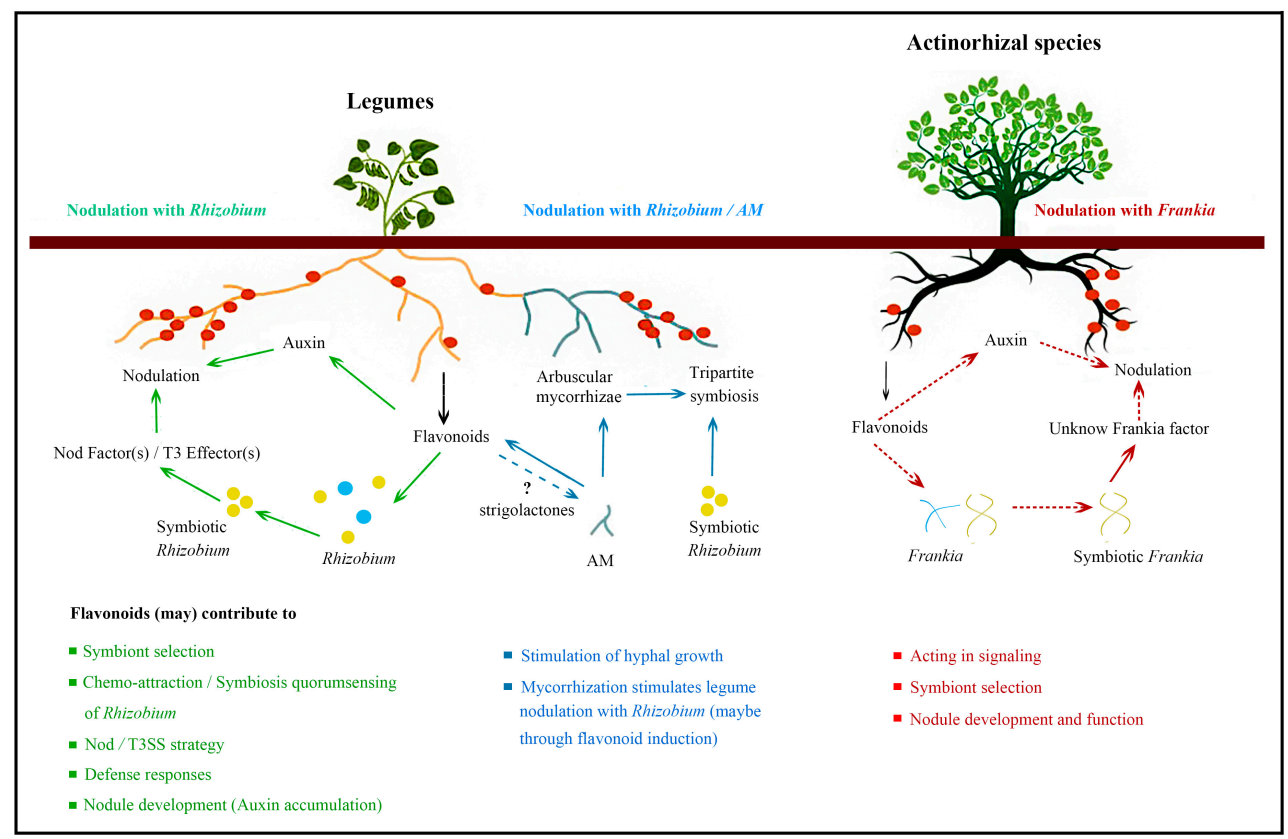

Figure 6. Schematic overview of flavonoid functions in the process of biological nitrogen fixation.

Author Contributions: All authors listed have made a substantial, direct contribution to the work, and approved it for publication. W.D. wrote the draft of the paper, Y.S. revised the paper. All authors have read and agreed to the published version of the manuscript.

Funding: This work was supported by the Young Talents Invitation Program of Shandong Provincial Colleges and Universities (2019-6-1). The National Natural Science Foundation of China (grant nos. 31300220, 31501328); Natural Science Foundation of Shandong Province (ZR2015JL012). 
Acknowledgments: Thanks to Robert Koebner (John Innes Centre, UK) for the grammar revision of the paper.

Conflicts of Interest: The authors declare no conflict of interest

\section{References}

1. Ferrer, J.L.; Austin, M.B.; Stewart, C.; Noel, J.P. Structure and function of enzymes involved in the biosynthesis of phenylpropanoids. Plant Physiol. Biochem. 2008, 46, 356-370. [CrossRef]

2. Winkel-Shirley, B. Flavonoid biosynthesis. A colorful model for genetics, biochemistry, cell biology and biotechnology. Plant Physiol. 2001, 126, 485-493. [CrossRef]

3. Winkel-Shirley, B. Biosynthesis of flavonoids and effects of stress. Curr. Opin. Plant Biol. 2002, 5, 218-223. [CrossRef]

4. Buer, C.S.; Imin, N.; Djordjevic, M.A. Flavonoids: New roles for old molecules. J. Integr. Plant Biol. 2010, 52, 98-111. [CrossRef]

5. Lopez-Meyer, M.; Paiva, N.L. Immonulocalization of vestitone reductase and isoflavone reductase, two enzymes involved in the biosynthesis of the phytoalexin medicarpin. Physiol. Mol. Plant Pathol. 2002, 61, 15-30. [CrossRef]

6. Mackenbrock, U.; Voselsang, R.; Barz, W. Isoflavone and pterocarpan malonylglucosides and $\beta$-1,3-glucan and chitin-hydrolases are vacuolar constituents in chickpea (Cicer arietinum L.). Z. Naturfr. C 1992, 47, 815-822. [CrossRef]

7. Cesco, S.; Neumann, G.; Tomasi, N.; Pinton, R.; Weisskopf, L. Release of plant-borne flavonoids into the rhizosphere and their role in plant nutrition. Plant Soil 2010, 329, 1-25. [CrossRef]

8. Fritz, C.; Palacios-Rojas, N.; Feil, R.; Stitt, M. Regulation of secondary metabolism by the carbon-nitrogen status in tobacco: Nitrate inhibits large sectors of phenylpropanoid metabolism. Plant J. 2006, 46, 533-548. [CrossRef] [PubMed]

9. Ververidis, F.; Trantas, E.; Douglas, C.; Vollmer, G.; Kretzschmar, G.; Panopoulos, N. Biotechnology of flavonoids and other phenylpropanoid-derived natural products. Part I: Chemical diversity, impacts on plant biology and human health. Biotechnol. J. 2007, 2, 1214-1234. [CrossRef] [PubMed]

10. Abdel-Lateif, K.; Bogusz, D.; Hocher, V. The role of flavonoids in the establishment of plant roots endosymbioses with arbuscular mycorrhiza fungi, rhizobia and Frankia bacteria. Plant Sign. Behav. 2012, 7, 636-641. [CrossRef] [PubMed]

11. Buer, C.S.; Muday, G.K.; Djordjevic, M.A. Flavonoids are differentially taken up and transported long distances in Arabidopsis. Plant Physiol. 2007, 145, 478-490. [CrossRef] [PubMed]

12. Vessey, J.K. Plant growth promoting rhizobacteria as biofertilizers. Plant Soil 2003, 255, 571-586. [CrossRef]

13. Vessey, J.K.; Katharina, P.; Birgitta, B. Plant and soil, root-based $\mathrm{N}_{2}$-fixing symbioses: Legumes, actinorhizal plants, Parasponia sp. and cycads. Plant Soil 2006, 266, 205-230. [CrossRef]

14. Abdel-Lateif, K.; Vaissayre, V.; Gherbi, H.; Verries, C.; Meudec, E.; Perrine-Walker, F.; Cheynier, V.; Svistoonoff, S.; Franche, C.; Bogusz, D.; et al. Silencing of the chalcone synthase gene in Casuarina Glauca highlights the important role of flavonoids during nodulation. New Phytol. 2013, 199, 1012-1021. [CrossRef]

15. Soltis, D.E.; Soltis, P.S.; Morgan, D.R.; Swensen, S.M.; Mullin, B.C.; Dowd, J.M.; Martin, P.G. Chloroplast gene sequence data suggest a single orgin of the predisposition for symbiotic nitrogen fixation in angiosperms. Proc. Natl. Acad. Sci. USA 1995, 92, 2647-2651. [CrossRef]

16. Gifford, I.; Battenberg, K.; Vaniya, A.; Wilson, A.; Tian, L.; Fiehn, O.; Berry, A.M. Distinctive patterns of flavonoid biosynthesis in roots and nodules of Datisca glomerata and Medicago spp. revealed by metabolomic and gene expression profiles. Front. Plant Sci. 2018, 9, 1463. [CrossRef]

17. Oldroyd, G.E.; Murray, J.D.; Poole, P.S.; Downie, J.A. The rules of engagement in the legume-rhizobial symbiosis. Annu. Rev. Genet. 2011, 45, 119-144. [CrossRef]

18. Hocher, V.; Alloisio, N.; Auguy, F.; Fournier, P.; Doumas, P.; Pujic, P.; Gherbi, H.; Queiroux, C.; Da Silva, C.; Wincker, P.; et al. Transcriptomics of actinorhizal symbioses reveals homologs of the whole common symbiotic signaling cascade. Plant Physiol. 2011, 156, 700-711. [CrossRef]

19. Martin, F.M.; Uroz, S.; Barker, D.G. Ancestral alliances: Plant mutualistic symbioses with fungi and bacteria. Science 2017, 356, 4501. [CrossRef] 
20. Frankow-Lindberg, B.E.; Dahlin, A.S. $\mathrm{N}_{2}$ fixation, $\mathrm{N}$ transfer, and yield in grassland communities including a deep-rooted legume or non-legume species. Plant Soil 2013, 370, 567-581. [CrossRef]

21. Guldan, S.J.; Martin, C.A.; Cueto-Wong, J.; Steiner, R.L. Interseeding legumes into chile: Legume productivity and effect on chile yield. Hort. Sci. 1996, 31, 1126-1128. [CrossRef]

22. Catherine, M.B.; Joel, L.S. Symbiotic nitrogen fixation by rhizobia-the roots of a success story. Curr. Opin. Plant Biol. 2018, 44, 7-15. [CrossRef]

23. Cooper, J.E. Early interactions between legumes and rhizobia: Disclosing complexity in a molecular dialogue. J. Appl. Microbiol. 2007, 103, 1355-1365. [CrossRef] [PubMed]

24. Peters, N.K.; Frost, J.W.; Long, S.R. A plant flavone, luteolin, induces expression of rhizobium meliloti nodulation genes. Science 1986, 233, 977-980. [CrossRef]

25. Redmond, J.W.; Batley, M.; Djordjevic, M.A.; Innes, R.W.; Kuempel, P.L.; Rolfe, B.G. Flavones induce expression of nodulation genes in Rhizobium. Nature 1986, 323, 632-635. [CrossRef]

26. Samira, H.; Ulrike, M. The role of flavonoids in root-rhizosphere signalling: Opportunities and challenges for improving plant-microbe interactions. J. Exp. Bot. 2012, 63, 3429-3444. [CrossRef]

27. Moscatiello, R.; Squartini, A.; Mariani, P.; Navazio, L. Flavonoid-induced calcium signalling in Rhizobium leguminosarum bv. viciae. New Phytol. 2010, 188, 814-823. [CrossRef]

28. Oldroyd, G.E. Speak, friend, and enter: Signalling systems that promote beneficial symbiotic associations in plants. Nat. Rev. Microbiol. 2013, 11, 252-263. [CrossRef]

29. Wang, Y.; Chen, S.; Yu, O. Metabolic engineering of flavonoids in plants and microorganisms. Appl. Microbiol. Biotechnol. 2011, 91, 949-956. [CrossRef]

30. Horvath, B.; Heidstra, R.; Lados, M.; Moerman, M.; Spaink, H.P.; Promé, J.C.; van Kammen, A.; Bisseling, T. Lipo-oligosaccharides of Rhizobium induce infection-related early nodulin gene expression in pea root hairs. Plant J. 1993, 4, 27-33. [CrossRef]

31. Cullimore, J.V.; Ranjeva, R.; Bono, J.J. Perception of lipochitooligosaccharidic Nod factors in legumes. Trends Plant Sci. 2001, 6, 24-30. [CrossRef]

32. Okazaki, S.; Kaneko, T.; Sato, S.; Saeki, K. Hijacking of leguminous nodulation signaling by the rhizobial type III secretion system. Proc. Natl. Acad. Sci. USA 2013, 110, 17131-17136. [CrossRef] [PubMed]

33. Krause, A.; Doerfel, A.; Gottfert, M. Mutational and transcriptional analysis of the type III secretion system of Bradyrhizobium japonicum. Mol. Plant Microbe Interact. 2002, 15, 1228-1235. [CrossRef] [PubMed]

34. Staehelin, C.; Krishnan, H.B. Nodulation outer proteins: Double-edged swords of symbiotic Rhizobia. Biochem. J. 2015, 470, 263-274. [CrossRef] [PubMed]

35. Lee, W.; Jeong, N.; Indrasumunar, A.; Gresshoff, P.; Jeong, S.C. Glycine max non-nodulation locus rj1: A recombinogenic region encompassing a SNP in a lysine motif receptor-like kinase (GmNFR1 $\alpha)$. Theor. Appl. Genet. 2011, 122, 875-884. [CrossRef]

36. Diepold, A.; Wagner, S. Assembly of the bacterial type III secretion machinery. FEMS Microbiol. Rev. 2014, 38, 802-822. [CrossRef]

37. Gazi, A.D.; Sarris, P.F.; Fadouloglou, V.E.; Charova, S.N.; Mathioudakis, N.; Panopoulos, N.J.; Kokkinidis, M. Phylogenetic analysis of a gene cluster encoding an additional, rhizobial-like type III secretion system that is narrowly distributed among Pseudomonas syringae strains. BMC Microbiol. 2012, 12, 188. [CrossRef]

38. Michiels, J.; Pelemans, H.; Vlassak, K.; Verreth, C.; Vanderleyden, J. Identification and characterization of a Rhizobium leguminosarum bv. phaseoli gene that is important for nodulation competitiveness and shows structural homology to a Rhizobium fredii host-inducible gene. Mol. Plant Microbe Interact. 1995, 8, 468-472. [CrossRef]

39. Okazaki, S.; Zehner, S.; Hempel, J.; Lang, K.; Gottfert, M. Genetic organization and functional analysis of the type III secretion system of Bradyrhizobium elkanii. FEMS Microbiol. Lett. 2009, 295, 88-95. [CrossRef]

40. Zhang, L.; Chen, X.J.; Lu, H.B.; Xie, Z.P.; Staehelin, C. Functional analysis of the type 3 effector nodulation outer protein L (NopL) from Rhizobium sp. NGR234: Symbiotic effects, phosphorylation, and interference with mitogen-activated protein kinase signaling. J. Biol. Chem. 2011, 286, 32178-32187. [CrossRef]

41. Krishnan, H.B.; Lorio, J.; Kim, W.S.; Jiang, G.Q.; Kim, K.Y.; DeBoer, M.; Pueppke, S.G. Extracellular proteins involved in soybean cultivar-specific nodulation are associated with pilus-like surface appendages and exported by a type III protein secretion system in Sinorhizobium fredii USDA257. Mol. Plant Microbe Interact. 2003, 16, 617-625. [CrossRef] [PubMed] 
42. Hartwig, U.A.; Maxwell, C.A.; Joseph, C.M.; Phillips, D.A. Effects of alfalfa nod gene-inducing flavonoids on nodABC transcription in Rhizobium meliloti strains containing different nodD genes. J. Bacteriol. 1990, 172, 2769-2773. [CrossRef] [PubMed]

43. Graham, T.L. Flavonoid and isoflavonoid distribution in developing soybean seedling tissues and in seed and root exudates. Plant Physiol. 1991, 95, 594-603. [CrossRef] [PubMed]

44. Zuanazzi, J.; Clergeot, P.H.; Quirion, J.C.; Husson, H.P.; Kondorosi, A.; Ratet, P. Production of Sinorhizobium meliloti nod gene activator and repressor flavonoids from Medicago sativa roots. Mol. Plant Microbe Interact. 1998, 11, 784-794. [CrossRef]

45. Aguilar, J.M.; Ashby, A.M.; Richards, A.J.; Loake, G.J.; Watson, M.D.; Shaw, C.H. Chemotaxis of Rhizobium leguminosarum towards flavonoid inducers of the symbiotic nodulation genes. J. Gen. Microbiol. 1988, 134, 2741-2746. [CrossRef]

46. Phillips, D.A.; Tsai, S.M. Flavonoids as plant signals to rhizosphere microbes. Mycorrhiza 1992, 1, 55-58. [CrossRef]

47. Hartwig, U.A.; Joseph, C.M.; Phillips, D.A. Flavonoids released naturally from alfalfa seeds enhance growth rate of Rhizobium meliloti. Plant Physiol. 1991, 95, 797-803. [CrossRef]

48. Nico, N.; Daniel, G.; Eric, G. The modification of the flavonoid naringenin by Bradyrhizobium sp. Strain ORS285 changes the nod genes inducer function to a growth stimulator. Mol. Plant Microb. Interact. 2019, 32, 1517-1525. [CrossRef]

49. Bennett, M.J.; Marchant, A.; May, S.T.; Swarup, R. Going the distance with auxin: Unravelling the molecular basis of auxin transport. Philos. Trans. R. Soc. B Biol. Sci. 1998, 35, 1511-1515. [CrossRef]

50. Eckhardt, N.A. The role of flavonoids in root nodule development and auxin transport in Medicago truncatula. Plant Cell 2006, 18, 1539-1540. [CrossRef]

51. Mathesius, U.; Schlaman, H.R.; Spaink, H.P.; Sautter, C.; Rolfe, B.G.; Djordjevic, M.A. Auxin transport inhibition precedes root nodule formation in white clover roots and is regulated by flavonoids and derivatives of chitin oligosaccharides. Plant J. 1998, 14, 23-34. [CrossRef] [PubMed]

52. Wasson, A.P.; Pellerone, F.I.; Mathesius, U. Silencing the flavonoid pathway in Medicago truncatula inhibits root nodule formation and prevents auxin transport regulation by rhizobia. Plant Cell 2006, 18, 1617-1629. [CrossRef] [PubMed]

53. Zhang, J.; Subramanian, S.; Stacey, G.; Yu, O. Flavones and flavonols play distinct critical roles during nodulation of Medicago truncatula by Sinorhizobium meliloti. Plant J. 2009, 57, 171-183. [CrossRef] [PubMed]

54. Subramanian, S.; Stacey, G.; Yu, O. Endogenous isoflavones are essential for the establishment of symbiosis between soybean and Bradyrhizobium japonicum. Plant J. 2006, 48, 261-273. [CrossRef]

55. Peer, W.A.; Murphy, A.S. Flavonoids and auxin transport: Modulators or regulators? Trends Plant Sci. 2007, 12, 556-563. [CrossRef]

56. Santelia, D.; Henrichs, S.; Vincenzetti, V.; Sauer, M.; Bigler, L.; Klein, M.; Bailly, A.; Lee, Y.; Friml, J.; Geisler, M.; et al. Flavonoids redirect PIN-mediated polar auxin fluxes during root gravitropic responses. J. Biol. Chem. 2008, 283, 31218-31226. [CrossRef]

57. Ripodas, C.; Dalla, V.V.; Aguilar, O.M.; Zanetti, M.E.; Blanco, F.A. Knock-down of a member of the isoflavone reductase gene family impairs plant growth and nodulation in Phaseolus vulgaris. Plant Physiol. Biochem. 2013, 68, 81-89. [CrossRef]

58. Wasson, A.P.; Ramsay, K.; Jones, M.G.; Mathesius, U. Differing requirements for flavonoids during the formation of lateral roots, nodules and root knot nematode galls in Medicago truncatula. New Phytol. 2009, 183, 167-179. [CrossRef]

59. Mathesius, U. Flavonoids induced in cells undergoing nodule organogenesis in white clover are regulators of auxin breakdown by peroxidase. J. Exp. Bot. 2001, 52, 419-426. [CrossRef]

60. Catford, J.G.; Staehelin, C.; Larose, G.; Piche, Y.; Vierheilig, H. Systemically suppressed isoflavonoids and their stimulating effects on nodulation and mycorrhization in alfalfa split-root systems. Plant Soil 2006, 285, 257-266. [CrossRef]

61. Van Zeijl, A.; Op den Camp, R.H.M.; Deinum, E.E.; Charnikhova, T.; Franssen, H.; Op den Camp, H.J.M.; Bouwmeester, H.; Kohlen, W.; Bisseling, T.; Geurts, R. Rhizobium lipo-chitooligosaccharide signaling triggers accumulation of cytokinins in Medicago truncatula roots. Mol. Plant 2015, 8, 1213-1226. [CrossRef] [PubMed]

62. Ng, J.L.P.; Hassan, S.; Truong, T.T.; Hocart, C.H.; Laffont, C.; Frugier, F.; Mathesius, U. Flavonoids and auxin transport inhibitors rescue symbiotic nodulation in the Medicago truncatula cytokinin perception mutant cre1. Plant Cell 2015, 27, 2210-2226. [CrossRef] 
63. Bailly, A.; Sovero, V.; Vincenzetti, V.; Santelia, D.; Bartnik, D.; Koenig, B.W.; Mancuso, S.; Martinoia, E.; Geisler, M. Modulation of P-glycoproteins by auxin transport inhibitors is mediated by interaction with immunophilins. J. Biol. Chem. 2008, 283, 21817-21826. [CrossRef] [PubMed]

64. Wang, B.; Bailly, A.; Zwiewka, M.; Henrichs, S.; Azzarello, E.; Mancuso, S.; Maeshima, M.; Friml, J.; Schulz, A.; Geisler, M. Arabidopsis TWISTED DWARF1 functionally interacts with auxin exporter ABCB1 on the root plasma membrane. Plant Cell 2013, 25, 202-214. [CrossRef]

65. Gil, P.; Dewey, E.; Friml, J.; Zhao, Y.; Snowden, K.C.; Putterill, J.; Palme, K.; Estelle, M.; Chory, J. BIG: A calossin-like protein required for polar auxin transport in Arabidopsis. Gene. Dev. 2001, 15, 1985-1997. [CrossRef] [PubMed]

66. Abd-Alla, M.H. Nodulation and nitrogen fixation in interspecies grafts of soybean and common bean is controlled by isoflavonoid signal molecules translocated from shoot. Plant Soil Environ. 2011, 57, 453-458. [CrossRef]

67. Noorden, G.E.; Ross, J.J.; Reid, J.B.; Rolfe, B.G.; Mathesius, U. Defective long-distance auxin transport regulation in the Medicago truncatula super numeric nodules mutant. Plant Physiol. 2006, 140, 1494-1506. [CrossRef]

68. Hayashi, M.; Saeki, Y.; Haga, M.; Harada, K.; Kouchi, H.; Umehara, Y. Rj (rj) genes involved in nitrogen-fixing root nodule formation in soybean. Breed. Sci. 2012, 61, 544-553. [CrossRef]

69. Gyorgypal, Z.; Kondorosi, E.; Kondorosi, A. Diverse signal sensitivity of NodD protein homologs from narrow and broad host range rhizobia. Mol. Plant Microbe Interact. 1991, 4, 356-364. [CrossRef]

70. Yokoyama, T. Flavonoid-responsive NodY-lacZ expression in three phylogenetically different Bradyrhizobium groups. Can. J. Microbiol. 2008, 54, 401-410. [CrossRef]

71. Yuan, S.; Li, R.; Chen, S.; Chen, H.; Zhang, C.; Chen, L.; Hao, Q.; Shan, Z.; Yang, Z.; Qiu, D.; et al. RNA-seq analysis of differential gene expression responding to different rhizobium strains in soybean (Glycine Max) roots. Front. Plant Sci. 2016, 7, 721. [CrossRef] [PubMed]

72. Pankhurst, C.E.; Biggs, D.R. Sensitivity of Rhizobium to selected isoflavonoids. Can. J. Microbiol. 1980, 26, 542-545. [CrossRef] [PubMed]

73. Maxwell, C.A.; Hartwig, U.A.; Joseph, C.M.; Phillips, D.A. A chalcone and two related flavonoids released from alfalfa roots induce nod genes of Rhizobium-meliloti. Plant Physiol. 1989, 91, 842-847. [CrossRef] [PubMed]

74. Roux, B.; Rodde, N.; Jardinaud, M.F.; Timmers, T.; Sauviac, L.; Cottret, L.; Carrière, S.; Sallet, E.; Courcelle, E.; Moreau, S.; et al. An integrated analysis of plant and bacterial gene expression in symbiotic root nodules using laser-capture microdissection coupled to rna sequencing. Plant J. 2014, 77, 817-837. [CrossRef]

75. Liu, C.; Murray, J.D. The role of flavonoids in nodulation host-range specificity: An update. Plants 2016, 5, 33. [CrossRef]

76. Janczarek, M. Environmental signals and regulatory pathways that influence exopolysaccharide production in Rhizobia. Int. J. Mol. Sci. 2011, 12, 7898-7933. [CrossRef]

77. Parniske, M.; Ahlborn, B.; Werner, D. Isoflavonoid-inducible resistance to the phytoalexin glyceollin in soybean rhizobia. J. Bacteriol. 1991, 173, 3432-3439. [CrossRef]

78. Akiyama, K.; Kawazu, K.; Kobayashi, A. Partially n-deacetylated chitin elicitor induces antimicrobial flavonoids in pea epicotyls. Z. Naturfr. C 1994, 49, 811-818. [CrossRef]

79. Lopez-Baena, F.J.; Monreal, J.A.; Perez-Montano, F.; Guasch-Vidal, B.; Bellogin, R.A.; Vinardell, J.M.; Ollero, F.J. The absence of Nops secretion in Sinorhizobium fredii HH103 increases GmPR1 expression in Williams soybean. Mol. Plant Microbe Interact. 2009, 22, 1445-1454. [CrossRef]

80. Cui, H.; Tsuda, K.; Parker, J.E. Effector-triggered immunity: From pathogen perception to robust defense. Annu. Rev. Plant Biol. 2015, 66, 487-511. [CrossRef]

81. Fuqua, C.; Parsek, M.R.; Greenberg, E.P. Regulation of gene expression by cell-to-cell communication: Acyl-homoserine lactone quorum sensing. Annu. Rev. Genet. 2001, 35, 439-468. [CrossRef] [PubMed]

82. Bodman, S.B.; Bauer, W.D.; Coplin, D.L. Quorum sensing in plant-pathogenic bacteria. Annu. Rev. Phytopathol. 2003, 41, 455-482. [CrossRef] [PubMed]

83. Vikram, A.; Jayaprakasha, G.K.; Jesudhasan, P.R.; Pillai, S.D.; Patil, B.S. Suppression of bacterial cell-cell signalling, biofilm formation and type III secretion system by citrus flavonoids. J. Appl. Microbiol. 2010, 109, 515-527. [CrossRef] 
84. Mathesius, U.; Mulders, S.; Gao, M.S.; Teplitski, M.; CaetanoAnolles, G.; Rolfe, B.G.; Bauer, W.D. Extensive and specific responses of a eukaryote to bacterial quorum-sensing signals. Proc. Natl. Acad. Sci. USA 2003, 100, 1444-1449. [CrossRef]

85. Vandeputte, O.M.; Kiendrebeogo, M.; Rajaonson, S.; Diallo, B.; Mol, A.; El Jaziri, M.; Baucher, M. Identification of catechin as one of the flavonoids from Combretum albiflorum bark extract that reduces the production of quorum-sensing-controlled virulence factors in Pseudomonas aeruginosa PAO1. Appl. Environ. Microbiol. 2010, 76, 243-253. [CrossRef]

86. Perez-Montano, F.; Guasch-Vidal, B.; Gonzalez-Barroso, S.; Lopez-Baena, F.J.; Cubo, T.; Ollero, F.J.; Gil-Serrano, A.M.; Rodriguez-Carvajal, M.A.; Bellogin, R.A.; Espuny, M.R. Nodulation-gene inducing flavonoids increase overall production of autoinducers and expression of $\mathrm{N}$-acyl homoserine lactone synthesis genes in rhizobia. Res. Microbiol. 2011, 162, 715-723. [CrossRef]

87. Rinaudi, L.V.; Giordano, W. An integrated view of biofilm formation in Rhizobia. FEMS Microbiol. Lett. 2010, 304, 1-11. [CrossRef]

88. Perez-Montano, F.; Jimenez-Guerrero, I.; Cerro, P.D.; Baena-Ropero, I.; López-Baena, F.J.; Ollero, F.J.; Bellogin, R.; Lloret, J.; Espuny, R. The symbiotic biofilm of Sinorhizobium Fredii SMH12, necessary for successful colonization and symbiosis of Glycine Max Cv Osumi, is regulated by quorum sensing systems and inducing flavonoids via NodD1. PLoS ONE 2014, 9, e105901. [CrossRef]

89. Dawson, J.O. Ecology of actinorhizal plants. In Nitrogen Fixation: Origins, Applications, and Research Progress; Pawlowski, K., Newton, W.E., Eds.; Springer: Dordrecht, The Netherlands, 2008; Volume 6, pp. 199-234.

90. Santi, C.; Bogusz, D.; Franche, C. Biological nitrogen fixation in non-legume plants. Ann. Bot. 2013, 111, 743-767. [CrossRef]

91. Benoit, L.; Berry, A. Flavonoid-like compounds from seeds of red alder (Alnus rubra) influence host nodulation by Frankia (Actinomycetales). Physiol. Plant 1997, 99, 588-593. [CrossRef]

92. Hughes, M.; Donnelly, C.; Crozier, A.; Wheeler, C.T. Effects of the exposure of roots of Alnus glutinosa to light on flavonoids and nodulation. Can. J. Bot. 1999, 77, 1311-1315. [CrossRef]

93. Ghelue, M.; Lovaas, E.; Ringo, E.; Solheim, B. Early interactions between Alnus glutinosa and Frankia strain ArI3. production and specificity of root hair deformation factor(s). Physiol. Plant 1997, 99, 579-587. [CrossRef]

94. Popovici, J.; Comte, G.; Bagnarol, E.; Alloisio, N.; Fournier, P.; Bellvert, F.; Bertrand, C.; Fernandez, M.P. Differential effects of rare specific flavonoids on compatible and incompatible strains in the Myrica gale-Frankia actinorhizal symbiosis. Appl. Environ. Microbiol. 2010, 76, 2451-2460. [CrossRef]

95. Hocher, V.; Auguy, F.; Argout, X.; Laplaze, L.; Franche, C.; Bogusz, D. Expressed sequence-tag analysis in Casuarina glauca actinorhizal nodule and root. New Phytol. 2006, 169, 681-688. [CrossRef]

96. Beauchemin, N.J.; Furnholm, T.; Lavenus, J.; Svistoonoff, S.; Doumas, P.; Bogusz, D.; Laplaze, L.; Tisa, L.S. Casuarina root exudates alter the physiology, surface properties, and plant infectivity of Frankia sp. Strain CcI3. Appl. Environ. Microbiol. 2012, 78, 575-580. [CrossRef] [PubMed]

97. Perrine-Walker, F.; Gherbi, H.; Imanishi, L.; Hocher, V.; Ghodhbane-Gtari, F.; Lavenus, J.; Benabdoun, F.M.; Nambiar-Veeti, M.; Svistoonoff, S.; Laplaze, L. Symbiotic signaling in actinorhizal symbioses. Curr. Protein Pept. Sci. 2011, 12, 156-164. [CrossRef]

98. Laplaze, L.; Gherbi, H.; Frutz, T.; Pawlowski, K.; Franche, C.; Macheix, J.J.; Auguy, F.; Bogusz, D.; Duhoux, E. Flavan-containing cells delimit Frankia-infected compartments in Casuarina glauca nodules. Plant Physiol. 1999, 121, 113-122. [CrossRef]

99. Kim, H.B.; Oh, C.J.; Lee, H.; An, C.S. A type-A chalcone isomerase mRNA is highly expressed in the root nodules of Elaeagnus umbella. J. Plant Biol. 2003, 46, 263-270. [CrossRef]

100. Péret, B.; Swarup, R.; Jansen, L.; Devos, G.; Auguy, F.; Collin, M.; Santi, C.; Hocher, V.; Franche, C.; Bogusz, D.; et al. Auxin influx activity is associated with Frankia infection during actinorhizal nodule formation in Casuarina Glauca. Plant Physiol. 2007, 144, 1852-1862. [CrossRef]

101. Hocher, V.; Alloisio, N.; Bogusz, D.; Normand, P. Early Signaling in Actinorhizal Symbioses. Plant Sign. Behav. 2011, 6, 1377-1379. [CrossRef]

102. Perrine-Walker, F.; Doumas, P.; Lucas, M.; Vaissayre, V.; Beauchemin, N.J.; Band, L.R.; Hocher, V.; Alloisio, N.; Auguy, F.; Fournier, P.; et al. Auxin carriers localization drives auxin accumulation in plant cells infected by Frankia in Casuarina Glauca actinorhizal nodules. Plant Physiol. 2010, 154, 1372-1380. [CrossRef] [PubMed] 
103. Auguy, F.; Abdel-Lateif, K.; Doumas, P.; Badin, P.; Guerin, V.; Bogusz, D.; Hocher, V. Activation of the isoflavonoid pathway in actinorhizal symbioses. Funct. Plant Biol. 2011, 38, 690-696. [CrossRef] [PubMed]

104. Harrison, M.J. Signaling in the arbuscular mycorrhizal symbiosis. Annu. Rev. Microbiol. 2005, 59, 19-42. [CrossRef] [PubMed]

105. Scervino, J.M.; Ponce, M.A.; Erra-Bassells, R.; Vierheilig, H.; Ocampo, J.A.; Godeas, A. Flavonoids exhibit fungal species and genus specific effects on the presymbiotic growth of Gigaspora and Glomus. Mycol. Res. 2005, 109, 789-794. [CrossRef] [PubMed]

106. Kikuchi, K.; Matsushita, N.; Suzuki, K.; Hogetsu, T. Flavonoids induce germination of basidiospores of the ectomycorrhizal fungus Suillus bovinus. Mycorrhiza 2007, 17, 563-570. [CrossRef] [PubMed]

107. Morandi, D.; le Signor, C.; Gianinazzi-Pearson, V.; Duc, G. A Medicago truncatula mutant hyper-responsive to mycorrhiza and defective for nodulation. Mycorrhiza 2009, 19, 435-441. [CrossRef] [PubMed]

108. Scheublin, T.R.; Marcel, G.A.; van der Heijden, M. Arbuscular Mycorrhizal fungi colonize nonfixing root nodules of several legume species. New Phytol. 2006, 172, 732-738. [CrossRef]

109. David, P.; Martina, J.; Alena, V.; Hana, G.; Miroslav, V.; Jan, J. Arbuscular Mycorrhiza stimulates biological nitrogen fixation in two Medicago spp. through improved phosphorus acquisition. Front. Plant Sci. 2017, 8 , 390. [CrossRef]

110. Zhang, W.; Sun, K.; Shi, R.; Yuan, J.; Wang, X.; Dai, C. Auxin signalling of Arachis Hypogaea activated by colonization of mutualistic fungus Phomopsis Liquidambari enhances nodulation and $\mathrm{N}_{2}$-fixation. Plant Cell Environ. 2018, 41, 2093-2108. [CrossRef]

111. Schliemann, W.; Ammer, C.; Strack, D. Metabolite profiling of mycorrhizal roots of Medicago truncatula. Phytochemistry 2008, 69, 112-146. [CrossRef]

112. Harrison, M.J.; Dixon, R.A. Spatial patterns of expression of flavonoid/isoflavonoid pathway genes during interactions between roots of Medicago truncatula and the mycorrhizal fungus Glomus versiforme. Plant J. 1994, 6, 9-20. [CrossRef]

113. Ponce, M.A.; Scervino, J.M.; Erra-Balsells, R.; Ocampo, J.A.; Godeas, A.M. Flavonoids from shoots and roots of Trifolium repens (white clover) grown in presence or absence of the arbuscular mycorrhizal fungus Glomus intraradices. Phytochemistry 2004, 65, 1925-1930. [CrossRef] [PubMed]

114. Morandi, D.; Bailey, J.A.; Gianinazzipearson, V. Isoflavonoid accumulation in soybean roots infected with vesicular arbuscular mycorrhizal fungi. Physiol. Plant Pathol. 1984, 24, 357-364. [CrossRef]

115. Kosslak, R.M.; Bookland, R.; Barkei, J.; Paaren, H.E.; Appelbaum, E.R. Induction of Bradyrhizobium japonicum common nod genes by isoflavones isolated from Glycine max. Proc. Natl. Acad. Sci. USA 1987, 84, 7428-7432. [CrossRef] [PubMed]

116. Antunes, P.M.; de Varennes, A.; Rajcanc, I.; Goss, M.J. Accumulation of specific flavonoids in soybean (Glycine $\max$ (L.) Merr.) as a function of the early tripartite symbiosis with arbuscular mycorrhizal fungi and Bradyrhizobium japonicum (Kirchner) Jordan. Soil Biol. Biochem. 2006, 38, 1234-1242. [CrossRef]

117. Antunesa, P.M.; Rajcan, I.; Goss, M.J. Specific flavonoids as interconnecting signals in the tripartite symbiosis formed by arbuscular mycorrhizal fungi, Bradyrhizobium japonicum (Kirchner) Jordan and soybean (Glycine max (L.) Merr.). Soil Biol. Biochem. 2006, 38, 533-543. [CrossRef]

118. Akiyama, K.; Matsuzaki, K.; Hayashi, H. Plant sesquiterpenes induce hyphal branching in arbuscular mycorrhizal fungi. Nature 2005, 435, 824-827. [CrossRef]

119. Steinkellner, S.; Lendzemo, V.; Langer, I.; Schweiger, P.; Khaosaad, T.; Toussaint, J.P.; Vieiheilig, H. Flavonoids and strigolactones in root exudates as signals in symbiotic and pathogenic plant-fungus interactions. Molecules 2007, 12, 1290-1306. [CrossRef]

120. Smith, D.L.; Zhang, F. Composition for Enhancing Grain Yield and Protein Yield of Legumes Grown under Environmental Conditions That Inhibitor Delay Nodulation. U.S. Patent 5,922,316, 25 June 1999.

121. Bais, H.P.; Vepachedu, R.; Gilroy, S.; Callaway, R.M.; Vivanco, J.M. Allelopathy and exotic plant invasion: From molecules and genes to species interactions. Science 2003, 301, 1377-1380. [CrossRef]

122. Weir, T.L.; Bais, H.P.; Vivanco, J.M. Intraspecific and interspecific interactions mediated by a phytotoxin, -catechin, secreted by the roots of Centaurea maculosa (spotted knapweed). J. Chem. Ecol. 2003, 29, 2397-2412. [CrossRef] 
123. Novak, K.; Chovanec, P.; Skrdleta, V.; Kropacova, M.; Lisa, L.; Nemcova, M. Effect of exogenous flavonoids on nodulation of pea (Pisum sativum L.). J. Exp. Bot. 2002, 53, 1735-1745. [CrossRef] [PubMed]

124. Morris, P.F.; Bone, E.; Tyler, B.M. Chemotropic and contact responses of Phytophthora sojae hyphae to soybean isoflavonoids and artificial substrates. Plant Physiol. 1998, 117, 1171-1178. [CrossRef] [PubMed]

125. Shaw, L.J.; Morris, P.; Hooker, J.E. Perception and modification of plant flavonoid signals by rhizosphere microorganisms. Environ. Microbiol. 2006, 8, 1867-1880. [CrossRef] [PubMed]

126. Gherbi, H.; Markmann, K.; Svistoonoff, S.; Estevan, J.; Autran, D.; Giczey, G.; Auguy, F.; Peret, B.; Laplaze, L.; Franche, C.; et al. SymRK defines a common genetic basis for plant root endosymbioses with AM fungi, rhizobia and Frankia bacteria. Proc. Natl. Acad. Sci. USA 2008, 105, 4928-4932. [CrossRef] [PubMed]

127. Beatty, P.H.; Good, A.G. Plant science. Future prospects for cereals that fix nitrogen. Science 2011, 333, 416-417. [CrossRef]

(C) 2020 by the authors. Licensee MDPI, Basel, Switzerland. This article is an open access article distributed under the terms and conditions of the Creative Commons Attribution (CC BY) license (http://creativecommons.org/licenses/by/4.0/). 